\title{
Integrating Local Culture to Promote Character Education In Teaching Writing
}

\author{
Fenny Thresia \\ Universitas Muhammadiyah Metro \\ fenny.thresia@yahoo.com
}

\begin{abstract}
Character education plays an important part because it is not only about moral and value education. It has a higher significance of moral education, because it not only teaches what is right and what is wrong. More than that character education inculcate the habit (habituation) about good things and wrong, can feel (affective domain) good value and used to do (behavioral domain). So the character education linked closely associated with persistent habits practiced or implemented. It is commonly believed that the practices of English language teaching always accompanied by the insertion of foreign cultural values which are not always in line with Indonesia cultural values. The aim of this study is to improve students' writing skill through integrating local culture material. Therefore this study focuses on designing and evaluating teaching writing material for English department students of University Muhammadiyah Metro. The result of this study shows that students have big interest and motivation in writing a text based on their local culture. The students also get moral value and character building through the material. It influences the students' character in their daily life. Students become more polite, honest, diligent and religious.
\end{abstract}

Keywords: local culture, character education, writing.

\section{INTRODUCTION}

Language has a central role in the development of intellectual, social, and emotional support learners and the success of the study all subjects. Therefore, learning English is designated as a communication tool as well as a means of self-development into Indonesian human learners who have global competitiveness.

Effective communication requires the use of correct grammar, ie, the language in accordance with the rules of language and communication demands of the context. Thus, although the 
linguistic knowledge should not be the focus in teaching and learning process but it still be taught .

Real communication always occurs in a natural context. Therefore, learning English should be conducted involving learners and their environment in the context of everyday life (authentic and natural).

English is a means of global communication. English mastery is expected to help learners understand and strengthen their local culture, as well as get to know and understand international culture. Therefore, learning English should be implemented with due regard to the three aspects of the culture. Sondarika (2013) found that teaching process through inserting local culture was effective to increase students' positive character.

It can be seen that character education plays a very important role, because it is not only focus on moral and value education. Slamet (2013) character education has a higher significance of moral education, because it is not only taught what is right and what is wrong. Moreover, character education inculcates the habit (habituation) about good things and wrong, can feel (affective domain) good value and used to do (behavioral domain). So the character education linked closely associated with persistent habits practiced or implemented (Ministry of Education, 2010a).

In learning English there are four skills that should mastered by the students, one of which is the ability to write or writing? In writing subject there is some material that must be mastered by the students such as the text in the form of descriptive, recount, report, procedure, news item, hortatory exposition, analytical exposition, explanation, discussion, and review (Genre-based Approach).

Channels that can be done in character education internalize the learning is through the development of a model-based learning model character. The character education can be formulated by incorporating elements of local culture or local culture. Through a problemsolving model, for example, a lot of character values that will be built up example of honesty, hard work, discipline, curiosity, creativity and others. Similarly, through a constructivist model, students will be nurtured character values such as character care about the environment, religious, recognize excellence, independent, and democratic.

Students in University Muhammadiyah of Metro have difficulties to elaborate their idea in writing. The students find difficulties to describe something strange with them, or 
they never see it before. Lack of knowledge makes students difficult to recall their background knowledge and to connect it with their culture. Most of materials in writing use native culture which is not suitable with the students' culture.

The possibility of lack of writing skills of students is caused by the low of students' motivation, or due to improper method of assessment, it could be due to low mastery of English grammar, or perhaps because of material improper and insufficient training frequency. The study was conducted to find out (a) if and (b) in what ways the material facilitate students' character and elaborate their writing skill.

In this study, the students were given the material that content local culture especially Lampung culture. They can enrich their knowledge about the culture and grow up the character education through some moral lesson and the value from the text.

\section{LOCAL CULTURE}

There are some ways to insert local culture in teaching material (Hartini, 2012); The teachers insert local culture in the forms of ideas (norms, moral, ethics, and religious values), activities (traditional ceremonies), and artifacts (historical or tourism places, food, and stories). Most of them are wrapped in texts. The insertion is done by selecting cultural topics, choosing cultural topics for classroom discussion, designing tasks or projects, and holding study tour to tourism places. There are several reasons for teachers inserting local culture. The reasons are that teachers are aware of the importance of local culture, so that students should not forget and be proud of their own culture. Local culture is also considered having better moral values and can help to create meaningful learning and it influences students' learning style (Goodson, 1993; Rao, 2002), views on testing, expectations of both students and teachers, and perceptions of the overall learning process (Gray, 1998; Hu, 2002; Kim, 2004; Simpson, 2008; Tan, 2005).

Culture and national character education is seen as a smart solution to produce students who have superior personality, morality, and uphold the values Indonesia thoroughly. According to Ajawaila (2009) local culture is the original culture of a certain group of people that also characterizes the culture of a local community group. But, it is not easy to formulate or define the concept of the local culture. According to Abdullah (2013), the definition of culture is almost always tied to the physical boundaries and geographical . For example, Javanese culture which refers to a tradition that developed in Java. Therefore, 
geographical boundaries have been used as the basis for formulating the definition of a local culture. However, in the process of socio-cultural change has emerged a tendency melting of the physical boundaries of a culture. It was influenced by the accelerating migration and the spread of global communications media so that no local culture of a community that is still so original.

According to Hartini (2012) in Indonesia there are currently more than 300 ethnic groups speaking 250 different languages and have different characteristics of local culture as well. The plurality of local culture in Indonesia is reflected in the diversity of cultures and customs of the society. Ethnic groups in Indonesia, such as Javanese, Sundanese, Batak, Minang, Timor, Bali, Sasak, Papua, and Maluku have customs and different languages. Each of these tribes grows and develops in accordance with the natural environment. Isolated geographical circumstances which led to the population of each island developing living patterns and customs are different.

\section{METHOD}

The subjects were fourty undergraduate students in English Departement Class in the second semester of the 2014 academic year at University Muhammadiyah of Metro Lampung Indonesia. The students writing skill is at the intermediate level. The purpose of using local culture material in writing subject are; the students is easier in recall their background knowldge about the topic and they can write many things.

\section{Instruments}

The instrument in this study is English material for writing subject that contain Lampung culture.

There are some steps before doing the treatments;

a) Decide the problem which appears in the subject of research.

b) Administering the pre-test to know student's writing ability before doing the action research.

c) Selecting materials for the treatment.

d) Implementing the technique in the teaching learning process.

e) Administering the pos-test to evaluate the result of action research and conducting the post assessment for the lecturer.

f) Analyzing all the data. 


\section{Process}

The sequences of action-reflection cycles CAR (Classroom Action Research) are:

\section{Planning}

Planning is the first step in each cycle. The researcher explains about what, why, where, who, and doing action. Without planning, this research hard to be focus. Therefore, the function of planning is to be reference in every researcher activity. He or she must follows the planning to make the research success. There are some steps that can be use to planning the research:

a) The researcher identifies the problem and finds the problem solving.

b) The researcher prepares the material and technique of teaching.

c) The researcher prepares the source of learning.

d) The researcher prepares guidance to observe and evaluate.

\section{Action}

Action is the second step in every cycle. It is the important part in the research. In other words, action is the implementation that doing in the class after the researcher makes the planning. The researcher tries to implementing the small discussion in the teaching learning process.

Here are the steps that the researcher does in the class:

a) The researcher makes the situation of class more relax.

b) The researcher gives the material about one topic (text).

c) The researcher gives direction for making a small group.

d) The researcher gives material that make students discuss with their group.

\section{Observation}

Observation is the activity of recording the event and action. Based on the observation, the researcher determines whether there is anything to improve, in order to achieve the aim of the research. The researcher observes them in every activity.

\section{Reflection}

The reflection is the last step in this research. The researcher will try to see and muse again something that the researcher has done. It is also to know the effect 
of the treatment to the students' learning process. By reflection, the researcher will know the strength and the weakness from the action in this research. After comparing the score distribution of pre-test and post-test, the researcher will review and reflection on the attitude and lecturer performance.

\section{DATA ANALYSIS}

The students' score will be conducted in each test by taking the average score of the pre-test and post-test furthermore to know the gain. Then, the result is matched by the minimum standard of writing score in this class at least 6.5. If the result scores of the students has been fulfilled more than 6.5 and $75 \%$ of the students has been passed, so the researcher can stop the research. If there are some students do not success in writing test, and it's about less than $75 \%$ of the total students, the researcher must continue in cycle II. The minimum cycle in Classroom research Action is two cycles.

\section{RESULTS}

The research was conducted in two cycles and the research began from the cycle I was done on February 9, 2015, than cycle II was done on March 5, 2015. Both of cycle I and II would be discussed more clearly as follows:

\section{Cycle I}

Cycle I was divided into planning, action, observation, and reflection. Firstly, the researcher conducted the pre-test score to know the student's score before treatment. It wll be used as the comparison score with post test score at the next.

Based on the result of pre-test score, there are 5 students $(12.5 \%)$ have score lower than 65. The minimum score of the students who are successful in mastering the material is 60. The average score of pre-test is 53. The result of pre-test gets the highest score is 70 and the lowest score is 40. It shows that the result of the students' writing ability in pre-test was not satisfactory. It is one reason why the researcher uses small group discussion as an alternative technique to teach writing.

\section{Planning}


The treatment was done on Friday February 14, 2015. It was opened by praying, greeting, checking the attendance list. At the day, the researcher takes the student's pre-test score. And the researcher has identified some problems and prepared the material directly.

Action

The second meeting was done on Friday, February 21, 2015. It was opened by praying, checking the attendance list and asking the condition of the students. The researcher as the lecturer gave direction to them for making small group contain 4 students in each group.

Firstly, lecturer read a teks about "Way Kambas" it is descriptive text. The lecturer gives a text to the students and read it together to get the main idea. The lecturer gives explanation about the pattern of the sentences that can be use in the descriptive text likes: simple past tense, simple past continuous tense, and many else. Lecturer shows how to summarize or re-write "Way Kambas" story.

The next step, the lecturer tells a story about "Pasir Putih Beach.". Then, lecturer asks all groups to discuss that story and write it with their own words. All members in each group should have job and role. When, the time was over the lecturer asks all groups to submit their paper job. Then lecturer suggests the students to study hard and gives them homework about descriptive text. After all, teh lecturer will close the class.

Learning process has gone well, the students get the point that lecturer wants. They undesrtood how to make descriptive text.

Time of learning process was over; the lecturer gave them suggestion to practice this technique in home. The lecturer also announces that next meeting would be test.

\section{Observation}

The researcher presented 1 meeting in cycle I. the researcher as the lecturer who is giving material about how to make descriptive text by grouping. Some students felt so happy and enjoyable with the situation of classroom whenever there are some students make condition of the class be noise and still there are students who did not help to finishing their job. Here are the explanations of the result of the student's observation and post-test I score, as follow: 


\section{a) Learning Process}

Based on the result score of student's observation sheet which attachment on appendix, it clasified category of the student's activity as follow:

Table 1

Table of the result of student's activities

\begin{tabular}{|c|c|c|c|c|}
\hline & Interval & Total & $\begin{array}{c}\text { Percenta } \\
\text { ges }\end{array}$ & Categories \\
\hline 1. & 5 & 2 & $5 \%$ & Excellent \\
\hline 2. & $3-4$ & 17 & $42.5 \%$ & Very good \\
\hline 3. & $1-2$ & 21 & $52.5 \%$ & Good \\
\hline \multicolumn{2}{|c|}{ Total } & 40 & $100 \%$ & \\
\hline
\end{tabular}

Source: Table of the result of observation Date : February 21, 2014

Based on table above, it can be inferred that the learning process was running well. It looked on there are $52.5 \%$ of the students on good categories, and $42.5 \%$ on very good categories, then $5 \%$ on excellent categories.

\section{b) The Result Score of Student's Post-test I}

After treatment process has done on February 21, 2015. So that, the researcher taken the post-test score on February 28, 2015 in order to know whether descriptive paragraph are able increased or not.

Based on the result of pre-test score, the researcher got the student's score by summarizing score from every point. The researcher also got average score by summarizing total score of all students and divided it with the total students. The result of pre-test can be identified as follows on the table to show that 21 students $(52.5 \%)$ have score lower than 65 . The average score of post test $I$ is 67 . The researcher was the highest score is 90 and the lowest score is 40 . It shows that the result of the students' writing ability in post test I was satisfactory.

\section{Reflection}

In this step, the researcher concluded that cycle I has achieved medium level of writing skill. But there are some students do not active in learning process. Because, there are $52.5 \%$ of the students were not active in the class. The only some students who active in 
group and not all students show their ability. This was happened because they are still confused and more like silent or enjoyable with their toys. The comparison of pre-test and post-test I score shown that satisfied. But the measurements of this research success are the satisfied score and the activeness of the students.

Some problems that should revise are time allocation of teaching, student's motivation, and management class. The lecturer felt so hard to managing the time in learning process. The management of class must be revised so that there is no students make a noise. Some students also still unfocused on learning process that make them have low score.

Based on the analyzing of learning process, the researcher concluded that this research should be continuing in cycle II.

\section{Cycle II}

Cycle II are similar with cycle I, it divided planning, action, observation, and reflection. It will explain more detail as follow:

\section{Planning}

Based on observation and reflection in cycle I, it showed that cycle I is success, but the researcher did not satisfied. Therefore, the researcher and lecturer tried to revise the several problems that appeared in cycle I and arranged the planning for continuing in cycle II. The researcher prepared the lesson plan such as the material, media, task, and evaluation for the first meeting and time allocation.

\section{Action}

The implementation of this cycle was done on 1 meeting. This meeting was done on March 7, 2015. This meeting was opening by greeting, checking attendance list, and motivating the students.

The researcher as the lecturer gave direction to them for making small group again contain 4 students in each group. It should choose the different friends with the first treatment. In this session, the lecturer asks all group to making a descriptive story. Lecturer guides the student about how to write a descriptive text. The lecturer also guides them to work together. So that the activeness of the students more focused.

Time of learning process was over; the lecturer gave them suggestion to all students to learn making descriptive text about what has done by them in home. The lecturer also announces that next meeting would be test again. 


\section{Observation}

In this step, the researcher presented 1 meeting. The lecturer gave material and made the students enthusiasm. The material is given by funny situation so made the students interesting.

Based on the result of observation sheet on cycle II, the researcher indicated that learning process in cycle II are success. Then, the result score of post-test is also satisfied. Here are the explanations of it:

\section{Learning Process}

Based on the which attachment on appendix, it clasified category of the student's activity as follow:

Table 5

The result of student's activities

\begin{tabular}{|c|c|c|c|c|}
\hline No. & Interval & Total & $\begin{array}{c}\text { Percenta } \\
\text { ges }\end{array}$ & Categories \\
\hline 1. & 5 & 11 & $27.5 \%$ & Excellent \\
\hline 2. & $3-4$ & 20 & $50 \%$ & Very good \\
\hline 3. & $1-2$ & 9 & $22.5 \%$ & Good \\
\hline \multicolumn{2}{|c|}{ Total } & 40 & $100 \%$ & \\
\hline
\end{tabular}

Source: Table of the result of observation sheet II

Date: March 7, 2014

Based on table above, it can be inferred that the learning process has done well. It looked on there are $22.5 \%$ of the students on good categories, and $50 \%$ on very good categories, then $27.5 \%$ on excellent categories. It is better than in cycle I.

\section{The Result Score of Student's Post-test II}

After the treatment, the students have good ability in writing descriptive text, and hopefully it also gives useful in others. It seen from the result score of post-test II, the researcher were the highest score is 90 and the lowest score is 50, while the average score are 76.5. There are 35 students that passed the exam with score $\geq 65$ with the percentage $87.5 \%$ in post-test II. It means that cycle II are very success. It shows that the result of the students' writing ability in post test was very satisfactory. 


\section{Reflection}

Based on the observation of learning process in cycle II, it can be inferred that the result of cycle II is success. The researcher felt satisfied about the result of the research. Based on the result above, the researcher concluded that this research is success and would be not continue in the next cycle.

\section{CONCLUSIONS}

Based on the result of the learning process on two cycles, the researcher would like to describe the conclusion that writing ability can be increased by using local culture material. Local culture can be used as an alternative way in learning process of writing. The student's activity in the implementation of cycle I and II was very active. It means that small group discussion can increase the student's activeness. The average student's activity in cycle I was $47.5 \%$ then increase to be $77.5 \%$ in cycle II. Local culture material makes students understand easily in writing ability. It looked on the progressing of the average score in every cycle, the average score of pre-test was 53, and in cycle I was 67 while in cycle II was 76.5 .

\section{REFERENCES}

Ajawaila. (2009). Prinsip Dasar Akhlak Mulia: Pengantar Studi KonsepKonsep Dasar Etika dalam Islam. Yogyakarta: Debut Wahana Press-FISE UNY.

Abdullah .(2008) .Pengembangan Karakter Anak Melalui Pendidikan Karakter. Tinjauan Beberapa Aspek Character Building.Yogyakarta:Kerjasama Lembaga Penelitian Unversitas Negeri Yogyakarta dan Tiara Wacana.

Goodson, T.J. (1993). Learning style preferences of East Asian ESL students. (Doctoral dissertation). Retrieved from http://trace.tennessee.edu/utk_graddiss/1254

Gray, R. (1998). Confucian conundrums: Higher education and ESL teaching in Korea and Japan. In Korea TESOL (Ed.),Proceedings of the 1998 Korea TESOL Conference. Paper presented at the 1998 Korea TESOL Conference Kyunghee University, Seoul, South Korea (pp. 45-50). Seoul, South Korea: KOTESOL.

Hartini, R. (2012). Studi mengenai insersi budaya lokal dalam pembelajaran oleh guru bahasa Inggris di Yogyakarta. Universitas Negeri Yogyakarta. Unpublished Thesis.

Hu, G. (2002). Potential cultural resistance to pedagogical imports: The case of Communicative Language Teaching in China. Language, Culture and Curriculum, 15(2), 93-105. http://dx.doi.org/10.1080/07908310208666636 
Kim, S. J. (2004). Coping with cultural obstacles to speaking English in the Korean Secondary School context. Asian EFL Journal,September 2004. Retrieved from http://www.asian-efl-journal.com/september 04 ksj.php

Li, M. (2003, November 29-December 3).

Culture and classroom communication: A case study of Asian students in New Zealand language schools. Paper presented at the joint NZARE-AARE Conference 2003 at University of Auckland, New Zealand. Auckland, New Zealand: NZARE-AARE

Peraturan Menteri Pendidikan Nasional

Republik Indonesia Nomor 23

Tahun 2006 tentang Standar Kompetensi Lulusan untuk Satuan Pendidikan Dasar dan Menengah.

Rao, Z.(2002). Bridging the gap between teaching and learning styles in East Asian contexts. TESOL Journal, 11(2), 5-11.

Simpson,S.T. (2008). Western EFL teachers and East-West classroom-culture conflicts. RELC Journal, 39(3) 381-394. http://dx.doi.org/10.1177/0033688208096847

Slamet. (2008). 100 Ways to Enhance Values and Morality in Schools and Youth Settings. Massachusetts: Allyn \& Bacon.

Sondarika.( 2013). Building Character in Schools: Practical Ways to Bring Moral Instruction to Life. San Francisco: Jossey Bass.

Tan, C. (2005). How culturally appropriate is the communicative approach for primary school children in Singapore? The Reading Matrix, 5(1),21-35. 